\title{
Responses of Young Peach Trees to Root Confinement
}

\author{
Mark Rieger \\ Department of Horticulture, University of Georgia, Athens, GA 30602 \\ Francesco Marra \\ Universitá degli Studi-Palermo, Istituto di Coltivazioni Arboree, Viale di Scienze, 90128, Palermo, Italy
}

Additional index words. Prunus persica, Nemaguard, root hydraulic conductivity, photosynthesis, nutrition, restricted root zone volume, nonstructural carbohydrates

\begin{abstract}
Rooted cuttings of Nemaguard peach [Prunus persica (L.) Batsch.] were grown in 0.18-, 0.36-, 0.90-, and 2.40liter containers for 16 weeks to study the influence of root confinement on growth, gas exchange, water uptake, and leaf carbohydrate and nutrient content. An automatic nutrient-solution dispensing system was used to ensure uniform fertility among treatments and to prevent drought stress. Leaf area and stem length were reduced by root confinement 6 to 7 weeks after transplanting, and differences among treatments increased throughout the experiment. Final tree dry weights were reduced by $51 \%$ over a 13 -fold reduction in rooting volume, but dry weight partitioning was largely unaffected. A temporary limitation to $\mathrm{CO}_{2}$ assimilation (A) and leaf conductance (g) was observed just after budbreak, but consistent reductions in $A$ and $g$ for confined trees did not occur until after week 11. Sorbitol and starch accumulated earlier in leaves of trees in smaller containers than larger containers. Despite similar fertility, concentrations of all nutrients except $\mathrm{N}$ and $\mathrm{Cu}$ were reduced $\approx \mathbf{2}$-fold for trees in $\mathbf{0}$.18-liter containers compared to other treatments. However, characteristics of nutrient deficiency were not observed on any trees, and growth reduction with no change in leaf nutrient content was observed in other treatments. It was concluded that the initial mechanisms limiting growth were not gas exchange rates, levels of nonstructural carbohydrates, or drought stress, although nutrient deficiency may have contributed to growth limitation in trees with severely confined root systems.
\end{abstract}

Controlling tree size is important in peach production, yet relatively few methods of growth control are available compared to other tree crops. Severe pruning is the only practical means of size control. While some pruning is necessary to stimulate growth of fruiting wood in peach, a reduction in pruning would greatly decrease production and labor costs (Ridley et al., 1985). Growth retardants reduce growth in peach but have occasional negative side effects on fruit quality (Loreti et al., 1989; Marini, 1987; Martin et al., 1987), may have perceived environmental or human health risks, and are frequently not registered for use on tree fruit. Size-controlling rootstocks are available for peach, but are not widely used due to one or more negative horticultural characteristics (Rom, 1983). Root pruning has been used successfully to control apple size (Geisler and Ferree, 1984), but initial studies on peach have shown negative effects on fruit yield and quality (Olien et al., 1991).

It is well established that confining the root system controls shoot growth in trees, as small containers and root pruning are elements of the ancient art of bonsai. Ran et al. (1992) showed that 4-year-old peach trees grown in 5- to 80-liter containers were reduced 5-fold between the smallest and largest containers. Myers and Savelle (1990) and Williamson and Coston (1990) also observed that field-grown peach trees were smaller when roots were confined by porous fabric, yet trees with confined roots had yield efficiency similar to or greater than larger, unconfined trees. These studies demonstrate the potential benefits of root confinement for peach production, yet little information is available concerning the physiological behavior of confined trees and the mechanism of growth control. Initial studies on peach suggest that a lack of root-derived hormones causes shoot growth reduction (Richards

Received for publication $22 \mathrm{Feb}$. 1993. Accepted for publication 27 July 1993. The cost of publishing this paper was defrayed in part by the payment of page charges. Under postal regulations, this paper therefore must be hereby marked advertisement solely to indicate this fact. and Rowe, 1977), yet evidence of water and nutrient limitations (Hameed et al., 1987; Tschaplinski and Blake, 1985) or anaerobiosis (Peterson et al., 1991b) was found in studies with other species.

Our objective was to characterize gas exchange, water uptake, and leaf nutrient and carbohydrate status of young peach trees in response to root confinement to increase our understanding of the physiological changes associated with growth reduction.

\section{Materials and Methods}

Plant material and growth conditions. Terminal semihardwood cuttings of 'Nemaguard' peach were taken from mature trees in Aug. 1991 and rooted as described by Couvillon and Erez (1980). Rooted cuttings were placed in a cooler at $7 \mathrm{C}$ for 10 weeks to satisfy the chilling requirement. Cuttings were removed from the cooler on 20 Dec. 1991 and transplanted to either 0.18-, 0.36-, $0.90-$, or 2.40-liter containers with coarse sand media. Plants were grown in a greenhouse with $80 \%$ light transmission, and minimum and maximum temperatures of 15 to $20 \mathrm{C}$ and 25 to $30 \mathrm{C}$, respectively, from Dec. 1991 to Apr. 1992. This time period was chosen to avoid supraoptimal soil temperatures that may occur during the summer. Peach root growth has a thermal optimum within the 15 to $30 \mathrm{C}$ range used in this study, with an upper limit for growth of $\approx 35 \mathrm{C}$ (Nightingale, 1935).

Plants were drip-irrigated with an automated nutrient-solution dispensing system. A soluble fertilizer $(20 \mathrm{~N}-8.6 \mathrm{P}-12 \mathrm{~K}$ plus trace elements) was injected into the irrigation line to yield $85 \mathrm{mg} \mathrm{N} / \mathrm{liter}$ $(6 \mathrm{~mm})$ at the emitter, but this was reduced to $17 \mathrm{mg} \mathrm{N} / \mathrm{liter}(1.2 \mathrm{~mm})$ after 6 weeks because lower leaves of some plants showed minor salt injury. The latter concentration maintained similar growth rates and eliminated symptoms of salt injury on leaves produced thereafter. Enough solution was applied at each watering so that the conductivity of the leachate was equal to the incoming solution $\left(0.20 \pm 0.02 \mathrm{dS} \cdot \mathrm{m}^{-1}\right)$ to ensure uniform soil nutrient concentration regardless of container volume. Irrigation frequency was increased 
from once per day to three times per day for $1.5 \mathrm{~h}$ per irrigation to prevent soil drying in smaller containers. All treatments had 12 or more single tree replications initially. However, several trees became visibly stressed due to deficient or excess soil water toward the end of the 16-week period and were removed; this reduced the number of replications available for data collection to six in all treatments.

Measurement of growth. Vegetative growth was measured weekly, beginning 5 weeks after transplanting (23 Jan. 1992) and ending 16 weeks after transplanting (except week 15-see below). Total leaf area was estimated on five trees per treatment by measuring length and width of all leaves and using Area = $0.66 \cdot($ length $\cdot$ width $)+0.43, r^{2}=0.99$. This equation was developed from measurements of length, width, and area (LI-3000 leaf area meter, LI-COR, Lincoln, Neb.) on 278 leaves from Nemaguard trees from the same population studied. Final leaf areas were measured directly after trees were destructively sampled 16 weeks after transplanting. Total length of stems, exclusive of the pre-existing stem, was measured simultaneously with leaf length and width measurements. Leaf expansion rates $\left(\mathrm{cm}^{2} \cdot \mathrm{day}^{-1}\right)$ and stem extension rates $\left(\mathrm{cm} \cdot \mathrm{day}^{-1}\right)$ were calculated by taking the difference between two consecutive weekly values and dividing by 7 . These rates, therefore, refer to the condition of the entire canopy rather than the growth rate of a single leaf or stem.

Sixteen weeks after transplanting, trees were separated into leaves, stems, roots $\leq 1 \mathrm{~mm}$ in diameter, and roots $>1 \mathrm{~mm}$ in diameter. Length of roots $\leq 1 \mathrm{~mm}$ in diameter was estimated according to the line-intersect method of Tennant (1975). All materials were dried at $80 \mathrm{C}$ for at least 1 week to obtain dry weight.

Gas exchange and root hydraulic conductivity. Carbon dioxide assimilation (A), transpiration (E), and leaf conductance (g) were measured weekly on four randomly selected trees in each treatment, beginning 16 Jan. and ending in mid-April. Measurements were made by enclosing up to $1000 \mathrm{~cm}^{2}$ of leaf area in a 42-liter, semi-closed gas-exchange chamber (Rieger and Motisi, 1990). Environmental conditions were air temperature of $26 \pm 2 \mathrm{C}$, vapor pressure deficit (VPD) of $2.0 \pm 0.2 \mathrm{kPa}, \mathrm{CO}_{2}$ concentration of 350 $\pm 10 \mu \mathrm{mol} \cdot \mathrm{mol}^{-1}$, and irradiance provided by three $400-\mathrm{W}$ metal halide lamps arranged in a $120^{\circ}$ arc around the chamber ranging from 1200 to $2500 \mu \mathrm{mol} \cdot \mathrm{m}^{-2} \cdot \mathrm{s}^{-1}$, depending on location. These conditions were maintained for all treatments and measurement dates. Intercellular $\mathrm{CO}_{2}$ concentration $\left(\mathrm{C}_{\mathrm{i}}\right)$ was calculated using $\mathrm{C}_{\mathrm{i}}$ $=\left[\mathrm{CO}_{2}\right]_{\text {out }}-\left(\mathrm{A} / \mathrm{g}_{\mathrm{CO} 2}\right)$, where $\left[\mathrm{CO}_{2}\right]_{\text {out }}$ is the $\mathrm{CO}_{2}$ concentration outside the leaves and $\mathrm{g}_{\mathrm{CO} 2}$ is the leaf conductance for $\mathrm{CO}_{2}$. Wateruse efficiency (WUE) was calculated as A/E.

Root hydraulic conductivity (Lp) was estimated (Rieger and Motisi, 1990) at the end of the growth period on six trees per treatment. These data were collected over 9 days, with measurement of treatments by replication to avoid bias due to order of measurement. This caused the interval between the last two measurements of all parameters to be 2 weeks instead of 1 week; hence, there were no data collected for week 15.

Leaf nutrient and nonstructural carbohydrate measurement. Leaf nutrient content was measured on oven-dried tissue at the end of the growth period. Nitrogen content was measured using Kjeldahl digestion of $0.5 \mathrm{~g}$ dried leaf tissue and colorimetric determination by autoanalyzer (Technicon). Concentrations of $\mathrm{P}, \mathrm{K}, \mathrm{Ca}, \mathrm{Mg}, \mathrm{Cu}$, $\mathrm{Fe}, \mathrm{Mn}, \mathrm{Zn}$, and B were determined using inductively coupled plasma spectroscopy on ashed leaf tissue (500C for $4 \mathrm{~h}$ ). Composite samples from all leaves in the canopy of six trees per treatment were used for nutrient analyses.

Nonstructural carbohydrates were extracted and determined according to Beaudry et al. (1990). Two-leaf samples from six trees per treatment were collected during the 9th, 13th, and 16th week after transplanting. Samples were collected at 1 PM on sunny days and stored immediately at $-18 \mathrm{C}$. A 100-mg sample of freeze-dried tissue was extracted with $10 \mathrm{ml}$ of $80 \%$ methanol containing $0.22 \mathrm{mg} \cdot \mathrm{ml}^{-1}$ of phenyl- $\beta$-D-glucopyranose as an internal standard, and a 100- $\mu$ l aliquot of the supernatant was analyzed by gas chromatography (Hewlett Packard 5890A, Avondale, Pa.) for sucrose, fructose, glucose, and sorbitol. Preliminary studies showed that these were the major soluble carbohydrates found in peach leaves. Buffer solution containing 3.75 units of amyloglucosidase per $100 \mu \mathrm{l}$ was then added to the solid fraction, which was incubated with citrate buffer $(\mathrm{pH}=4.5-5.0)$ at $60 \mathrm{C}$ for $48 \mathrm{~h}$ to hydrolyze starch to glucose. A $100 \mu \mathrm{l}$ sample of this supernatant was prepared for gas chromatography exactly as were soluble sugar samples. Xylitol $\left(0.2 \mathrm{mg} \cdot \mathrm{ml}^{-1}\right)$ was used as an internal standard for starch.

All data were analyzed by regression and orthogonal contrast, the latter used only where specific tests were desired. Linear, quadratic, and cubic models were tested, and the models presented were those with significant coefficients $(P<0.05)$ and significant $r^{2}$ improvement over the next-lowest model.

\section{Results}

Growth. Total dry weight per tree increased linearly with container volume, being about 2-fold greater in the largest compared to the smallest container (Table 1). However, the proportion of dry weight in leaves, stems, and roots was relatively unchanged. Only the percentage of dry matter in leaves decreased (by $5 \%$ ) with increased container volume, whereas dry-matter allocation to stems and roots was not affected (Table 1). Increased percentage

Table 1. Growth parameters of 'Nemaguard' peach trees 16 weeks after transplanting to containers of various volumes.

\begin{tabular}{|c|c|c|c|c|c|c|c|c|}
\hline $\begin{array}{l}\text { Container } \\
\text { volume } \\
\text { (liter) }\end{array}$ & $\begin{array}{l}\text { Total } \\
\text { dry wt } \\
(\mathrm{g})\end{array}$ & $\begin{array}{c}\text { Leaf } \\
\text { biomass } \\
(\% \text { of total })\end{array}$ & $\begin{array}{c}\text { Root } \\
\text { biomass } \\
(\% \text { of total })\end{array}$ & $\begin{array}{c}\text { Stem } \\
\text { biomass } \\
(\% \text { of total })\end{array}$ & $\begin{array}{c}\text { Fibrous root } \\
\text { wt } \% \\
\text { (\% of total } \\
\text { root dry wt) }\end{array}$ & $\begin{array}{l}\text { Specific } \\
\text { root length } \\
(\mathrm{m} / \mathrm{g})\end{array}$ & $\begin{array}{c}\text { Leaf } \\
\text { area : root } \\
\text { length ratio } \\
\left(\mathrm{m} \times 10^{3}\right)\end{array}$ & $\begin{array}{c}\text { Specific leaf } \\
\text { area } \\
\left(\mathrm{m}^{2} \mathrm{~g}^{-1} \times 10^{2}\right)\end{array}$ \\
\hline 2.40 & 39.2 & 45.5 & 21.4 & 33.0 & 59 & 52.5 & 1.13 & 1.84 \\
\hline 0.90 & 27.2 & 47.4 & 21.8 & 30.8 & 59 & 53.7 & 1.14 & 1.65 \\
\hline 0.36 & 23.3 & 49.8 & 21.1 & 29.1 & 62 & 42.3 & 1.29 & 1.41 \\
\hline 0.18 & 19.2 & 50.1 & 18.6 & 31.3 & 59 & 42.2 & 1.47 & 1.31 \\
\hline \multicolumn{9}{|l|}{ Linear } \\
\hline regression & $* * *$ & $* *$ & NS & NS & NS & $* *$ & NS & $* *$ \\
\hline$r^{2}$ & 0.68 & 0.30 & 0.08 & 0.13 & 0.04 & 0.30 & 0.03 & 0.30 \\
\hline
\end{tabular}

$\overline{\mathrm{Ns},},{ }^{*},{ }^{* *},{ }^{* * *}$ Nonsignificant or significant at $P<0.05, P<0.01$, or $P<0.001$, respectively. 


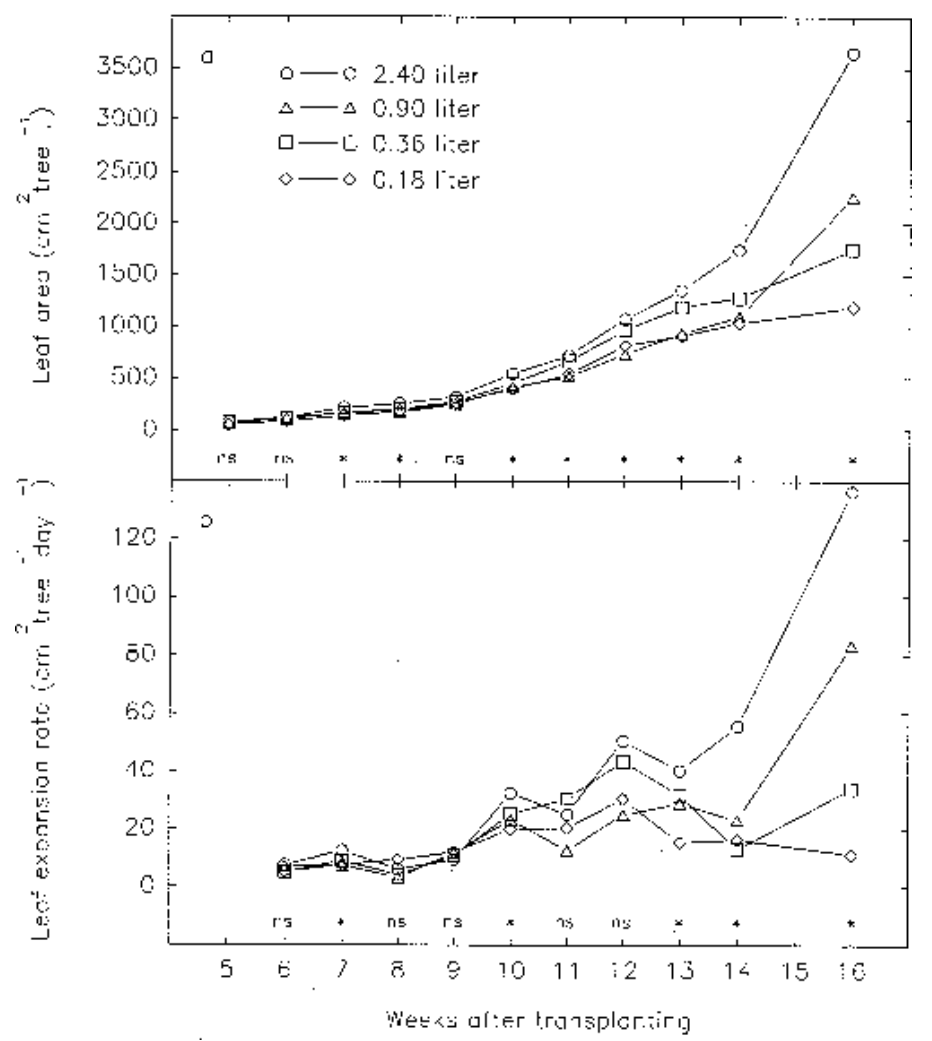

Fig. 1. Leaf area (a) and leaf area expansion rate (b) for Nemaguard peach trees grown in containers of volumes indicated for 16 weeks. ${ }^{\mathrm{Ns}, * \text { Nonsignificant or }}$ significant at $P<0.05$ respectively, of linear regressions for each week.

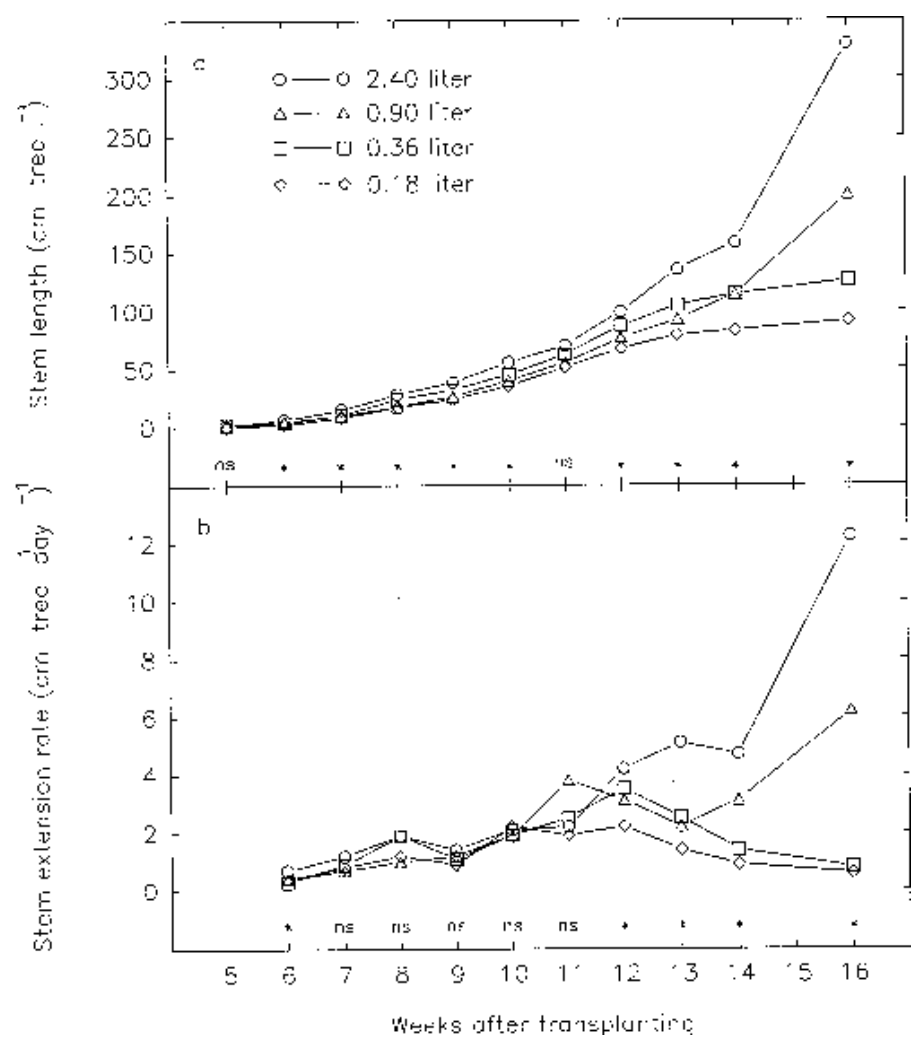

Fig. 2. Total length of new stems (a) and stem extension rate (b) for Nemaguard peach trees grown in containers of volumes indicated for 16 weeks. Ns, $*$ Nonsignificant or significant at $P<0.05$ respectively, of linear regressions for each week.

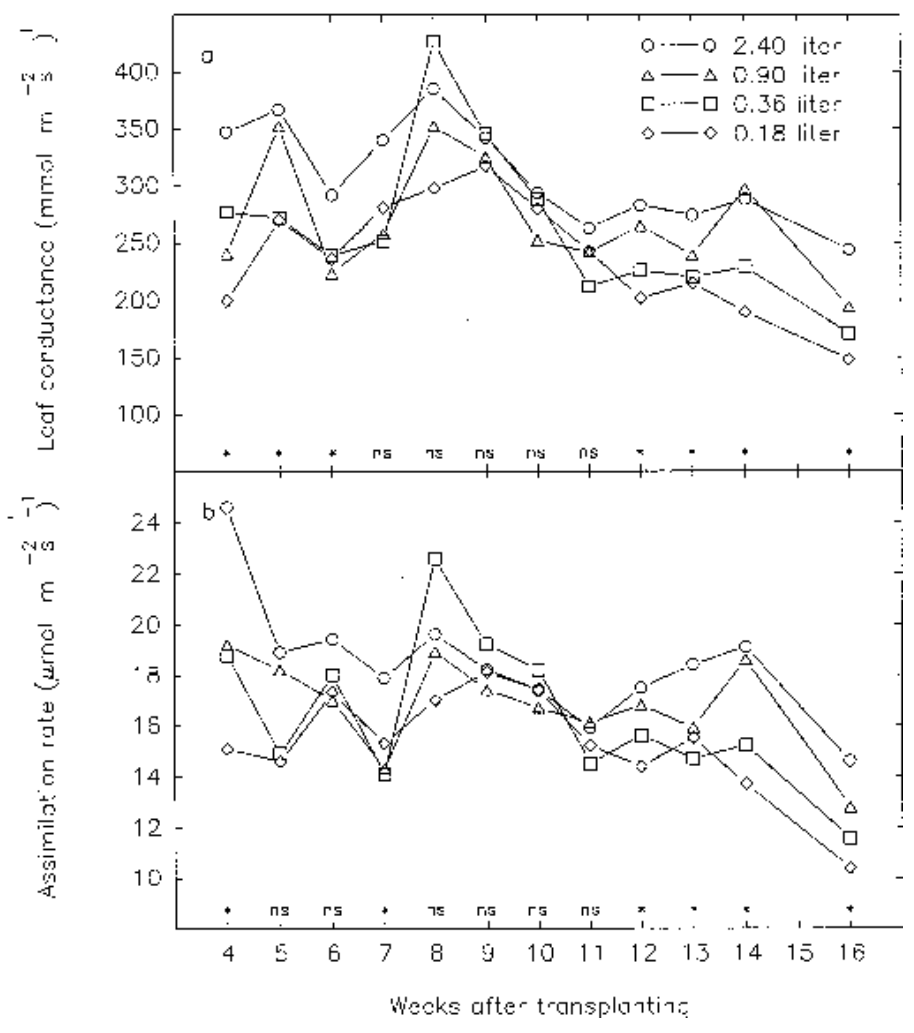

Fig. 3. Leaf conductance (a) and net $\mathrm{CO}_{2}$ assimilation rate (b) for Nemaguard peach trees grown in containers of volumes indicated for 16 weeks. ${ }^{\text {Ns, } * \text { Nonsignificant }}$ or significant at $P<0.05$ respectively, of linear regressions for each week.

leaf biomass as growth was reduced caused specific leaf area (SLA) to increase with container volume. Root : shoot ratio, leaf area : root length ratio, and the proportion of root dry matter in fibrous roots $(\leq 1 \mathrm{~mm}$ in diameter) were not influenced by container volume.

Leaf area was linearly related to container volume from 7 weeks after transplanting throughout the experiment $(P<0.05)$ with the exception of week 9, when the significance level was $P=0.07$ (Fig. 1a). Final leaf area was $>3$-fold greater in the largest vs. smallest container treatment. Leaf expansion rate was inconsistently affected by container size over time (Fig. 1b); differences in leaf area occurred on weeks 8,11 , and 12 despite similar expansion rates among treatments on those dates. Leaf expansion rates were highest for trees in larger containers on the last measurement date (week 16), whereas rates peaked at week 12 for the two smaller container volumes.

Stem length increased with container volume from week 6 throughout the experiment, except week 11, when significance level was $P=0.07$ (Fig. 2a). As with leaf area, differences in stem length were not always related to differences in stem extension rate among treatments. Maximal rates of stem extension were reached at week 12 for the two smaller container volumes, but week 16 for trees in the two larger container volumes (Fig. 2b).

Gas exchange and root hydraulic conductivity. With the exception of weeks 4 and 7, A was similar among treatments until week 12, when consistent, linear increases in A with container volume occurred until the end of the experiment (Fig. 3b). Contrasts showed that trees in 2.4-liter containers had higher $\mathrm{g}$ than other trees during weeks 4 to 6 , yet A was higher for these trees only on week 4. At the end of the experiment, A and g were reduced by $29 \%$ and $39 \%$, respectively, between the largest and 
Table 2. Nutrient content per unit leaf area $\left(\mathrm{mmol} \cdot \mathrm{m}^{-2}\right)$ and $\mathrm{N}$ use efficiency (NUE) of Nemaguard peach trees 16 weeks after transplanting to containers of various volumes.

\begin{tabular}{|c|c|c|c|c|c|c|c|c|c|c|c|}
\hline \multirow[b]{2}{*}{$\begin{array}{l}\text { Container } \\
\text { volume } \\
\text { (liter) }\end{array}$} & \multicolumn{10}{|c|}{ Nutrient content } & \multirow{2}{*}{$\begin{array}{c}\text { NUE } \\
(\mathrm{mol} \mathrm{C} / \\
\text { mol N per } \\
\left.\sec \times 10^{5}\right)\end{array}$} \\
\hline & $\mathrm{P}$ & $\mathrm{K}$ & $\mathrm{Ca}$ & $\mathrm{Mg}$ & $\begin{array}{c}\mathrm{Cu} \\
\left(\times 10^{2}\right)\end{array}$ & $\begin{array}{c}\mathrm{Fe} \\
\left(\times 10^{2}\right)\end{array}$ & $\underset{\left(\times 10^{2}\right)}{\mathrm{Mn}}$ & $\underset{\left(\times 10^{2}\right)}{\mathrm{Zn}}$ & $\begin{array}{c}\mathrm{B} \\
\left(\times 10^{2}\right)\end{array}$ & $\mathrm{N}$ & \\
\hline 2.40 & 5.1 & 35.7 & 8.4 & 5.3 & 6.1 & 9.0 & 9.7 & 8.6 & 21 & 128 & 11.4 \\
\hline 0.90 & 5.7 & 37.8 & 9.2 & 6.1 & 7.5 & 9.3 & 11.9 & 10.6 & 24 & 133 & 9.6 \\
\hline 0.36 & 5.4 & 40.8 & 8.5 & 6.0 & 10.2 & 10.6 & 10.6 & 7.6 & 24 & 131 & 8.9 \\
\hline 0.18 & 2.3 & 16.5 & 3.5 & 2.6 & 3.4 & 4.0 & 3.2 & 3.4 & 9 & 131 & 8.0 \\
\hline \multicolumn{12}{|c|}{ Quadratic } \\
\hline$r^{2}$ & 0.58 & 0.40 & 0.60 & 0.51 & 0.13 & 0.25 & 0.56 & 0.82 & 0.48 & 0.03 & 0.50 \\
\hline
\end{tabular}

Table 3. Leaf carbohydrate content ( $\mathrm{mg} \cdot \mathrm{g}^{-1}$ dry weight) of Nemaguard peach trees 9,13 , and 16 weeks after transplanting to containers of various volumes.

\begin{tabular}{|c|c|c|c|c|c|}
\hline $\begin{array}{l}\text { Container } \\
\text { volume } \\
\text { (liter) }\end{array}$ & Fructose & Glucose & Sucrose & Sorbitol & $\begin{array}{r}\text { Starch } \\
\text { (glucose } \\
\text { equiva- } \\
\text { lents) }\end{array}$ \\
\hline \multicolumn{6}{|c|}{ Week 9} \\
\hline 2.40 & 20.3 & 27.0 & 2.8 & 53.7 & 8.1 \\
\hline 0.90 & 21.2 & 25.4 & 1.5 & 54.4 & 8.1 \\
\hline 0.36 & 20.2 & 27.1 & 2.0 & 66.2 & 12.2 \\
\hline 0.18 & 20.5 & 26.7 & 2.0 & 66.6 & 9.4 \\
\hline \multicolumn{6}{|l|}{ Linear } \\
\hline regression & NS & NS & NS & $*$ & NS \\
\hline$r^{2}$ & 0.00 & 0.00 & 0.04 & 0.19 & 0.01 \\
\hline \multicolumn{6}{|c|}{ Week 13} \\
\hline 2.40 & 24.1 & 27.6 & 5.6 & 87.4 & 18.0 \\
\hline 0.90 & 21.3 & 23.4 & 8.8 & 82.6 & 30.6 \\
\hline 0.36 & 24.1 & 26.0 & 6.3 & 89.6 & 86.9 \\
\hline 0.18 & 20.9 & 23.6 & 5.1 & 87.3 & 98.6 \\
\hline \multicolumn{6}{|l|}{ Linear } \\
\hline regression & NS & $*$ & NS & NS & $* * *$ \\
\hline$r^{2}$ & 0.10 & 0.21 & 0.00 & 0.00 & 0.45 \\
\hline \multicolumn{6}{|c|}{ Week 16} \\
\hline 2.40 & 17.2 & 19.9 & 18.7 & 94.3 & 99.1 \\
\hline 0.90 & 16.9 & 17.5 & 16.6 & 89.8 & 93.0 \\
\hline 0.36 & 15.2 & 15.7 & 16.6 & 87.0 & 94.4 \\
\hline 0.18 & 14.4 & 14.6 & 15.4 & 81.5 & 121.1 \\
\hline \multicolumn{6}{|l|}{ Linear } \\
\hline regression & $*$ & $* * *$ & NS & $* * *$ & NS \\
\hline$r^{2}$ & 0.16 & 0.43 & 0.13 & 0.42 & 0.03 \\
\hline
\end{tabular}
respectively.

smallest container volumes.

$\mathrm{C}_{\mathrm{i}}$ ranged from 220 to $270 \mu \mathrm{mol} \cdot \mathrm{mol}^{-1}$, but never differed among treatments (data not shown). $\mathrm{C}_{\mathrm{i}}$ was positively correlated with both $\mathrm{A}(r=0.22, P=0.0017)$ and $\mathrm{g}(r=0.68, P<0.0001)$ when data were pooled. WUE also did not differ among treatments, but was negatively correlated with $\mathrm{g}(r=-0.57, P<0.0001)$ (data not shown).

Root hydraulic conductivity did not differ among treatments, nor did the gradient across the root system at zero flow (offset).
Root hydraulic conductivity ranged from 0.48 to $0.73 \mathrm{~g} \cdot \mathrm{h}^{-1} \cdot \mathrm{m}^{-}$ ${ }^{1} \cdot \mathrm{MPa}^{-1}$, and offset values were consistently $-0.3 \mathrm{MPa}$ regardless of container volume. These values were similar to those obtained on young Nemaguard trees in previous studies (Rieger, 1992; Rieger and Motisi, 1990).

Leaf nutrient and carbohydrate content. Leaf nutrient concentration $\left(\mathrm{mmol} \cdot \mathrm{m}^{-2}\right)$ was curvilinearly related to container volume except for $\mathrm{Cu}$ and $\mathrm{N}$ (Table 2). There was significant $r^{2}$ improvement of the quadratic over the linear regression model. Nutrient concentration increased more than 2 -fold between 0.18 liters and the other container volumes collectively. Trees in 0.18-liter containers had concentrations of $\mathrm{P}, \mathrm{K}, \mathrm{Ca}, \mathrm{Mg}, \mathrm{Fe}, \mathrm{Mn}$, and $\mathrm{B}$ characterized as deficient for peach trees in Georgia (Ferree and Myers, 1989), yet characteristic signs of deficiency were not observed. The combination of similar leaf $\mathrm{N}$ content and lower $\mathrm{A}$ as container volume decreased caused nitrogen use efficiency (NUE) to decrease with container volume.

Sorbitol was the most abundant nonstructural carbohydrate found in leaves at weeks 9 and 13, although starch content equalled or exceeded sorbitol by week 16 (Table 3 ). Container volume had variable effects on sorbitol concentration. At week 9, sorbitol was $22 \%$ higher for trees in smaller compared to larger containers; at week 13, there was no effect of container volume on sorbitol; at week 16 the pattern was reversed, as sorbitol increased with container volume. There was a 5-fold decrease in leaf starch between the smallest and largest container volumes at week 13, although no difference in starch was detected on other dates. At week 16, only starch and sucrose were not affected by container volume; other carbohydrates increased with container size. Quantities of starch and sugars for trees in 2.4-liter containers were similar to those reported for 'Redhaven'/Halford trees after a comparable growth period (Rom and Ferree, 1985).

\section{Discussion}

Growth. Confining the root system caused a $51 \%$ reduction in total dry weight over a 13 -fold decrease in rooting volume. This is comparable to data of Ran et al. (1992), who observed a 72\% reduction in dry weight of 1-year-old peach trees over a 16-fold decrease in rooting volume. The greater reduction in the study of Ran et al. (1992) may be due to a longer growth period and/or a larger change in rooting volume than in this study. Another similarity between these two studies was the small effect of root confinement on dry-matter partitioning among organs. In our study, only the percentage of dry matter in leaves was reduced by 
root confinement, whereas no changes in partitioning among leaves, stems, or roots were observed by Ran et al. (1992). Similarly, no change in root : shoot ratio was observed in peach seedlings due to root confinement (Richards and Rowe, 1977). Thus, it seems that root confinement does not materially affect dry weight partitioning in peach, similar to the response of soybean (Krizek et al., 1985) and cucumber (Robbins and Pharr, 1988), but in contrast to studies on tomato (Hameed et al., 1987, Peterson et al., 1991a, Ruff et al., 1987), wheat (Peterson et al., 1984), lupin (Pigeaire et al., 1990), and bean (Carmi et al., 1983).

Decreased specific leaf area (SLA) and specific root length (SRL) in response to root confinement (Table 1) were also observed in tomato (Hameed et al., 1987), in which the increased mass per volume was attributed to accumulation of photosynthate in response to lack of active sinks in confined plants. In our study, leaves had comparable levels of nonstructural carbohydrates when SLA was measured, so the increase in SLA must have been due to increases in structural carbohydrates or other compounds. Lower SRL for trees in smaller containers may decrease nutrient uptake capacity per unit root mass (Eissenstat, 1992), and therefore may have been a factor contributing to reduced leaf nutrient concentrations in trees in 0.18-liter containers. However, Lp was not related to changes in SRL, in contrast to the correlation between Lp and SRL in citrus (Eissenstat, 1992).

Differences in stem length and extension rate among treatments occurred as early as 3 weeks after budbreak (week 6), and leaf area and expansion rate were first affected 1 week later (Figs. 1 and 2). Both processes were affected several weeks before the time when A was affected consistently by container volume, suggesting that differences in stem and leaf growth were not the result of a limitation of photosynthesis. This is further supported by the carbohydrate data, where quantities of nonstructural carbohydrates were equal or greater for trees in smaller vs. larger containers, so that photosynthate use was reduced by root confinement earlier than photosynthate production (Table 3). Similarly, Carmi et al. (1983) reported that growth of bean plants was reduced by root confinement despite similar or higher A for confined plants.

It is unlikely that water deficit caused the reduction in growth, although some of the responses to root confinement observed here are consistent with effects of drought stress (Krizek et al., 1985). First, trees in all treatments had similar fibrous root weight fraction, root : shoot and leaf area : root length ratios, and Lp, suggesting a balance between water uptake and transpiration capacities. While studies have shown that water deficits can develop in plants with confined roots despite hydroponic growth conditions (Hameed et al., 1987; Tschaplinski and Blake, 1985), drought stress in these cases was associated with reductions in root : shoot ratio and/or Lp. Second, the onset of growth reduction during weeks 6 and 7 occurred when trees were small and only one irrigation per day maintained soil at high water content. However, mild water deficit could have occurred without visible wilting later in the study, and this may have accentuated pre-existing differences in growth.

Gas exchange and water uptake. Carbon dioxide assimilation and $g$ were affected by container volume by the greatest amount on week 4, shortly after budbreak, when no differences in shoot growth were observed. An effect of container volume on A and $g$ at such an early stage was unexpected. Roots in the smallest containers may have experienced mechanical impedance with the container walls, since many roots were observed at the soilcontainer interface before budbreak, whereas this was not observed in larger containers. Evidence that shoot growth can be affected very early by mechanical impedance to roots was found with wheat, where seedlings exhibited reduced leaf expansion just 2 days after germination, and had lower $\mathrm{g}$ before expansion of the second true leaf (Masle and Passioura, 1987). Water, nutrient, or carbohydrate supply were not limiting at that time, and it was conjectured that reduced leaf growth and g occurred in response to a root-derived hormonal signal (Masle and Passioura, 1987). Abscisic acid production in roots and translocation to shoots in response to soil drying has been documented (Blackman and Davies, 1985), and it is possible that the early effects on gas exchange and growth observed here resulted from a similar mechanism. Root-sourced hormones have been implicated in growth control of peach trees with confined roots (Richards and Rowe, 1977). The recovery of $A$ and $g$ to levels similar to trees in larger containers following week 4 may indicate that gas exchange can recover from stresses produced by root confinement, whereas leaf and stem growth cannot.

Intercellular $\mathrm{CO}_{2}$ did not differ among treatments, although differences in $\mathrm{A}$ and $\mathrm{g}$ were observed. Similar levels of $\mathrm{C}_{\mathrm{i}}$ among treatments with different A suggests a nonstomatal limitation to $\mathrm{A}$ in response to root confinement. The simultaneous reduction in A and $\mathrm{E}$ from stomatal closure in confined trees maintained WUE constant across treatments-further evidence that water imbalance is not necessarily a consequence of root confinement.

Leaf nutrient and nonstructural carbohydrate content. Despite exposure of roots to the same nutrient solution in all treatments, a large decrease in leaf nutrient content was observed for trees in 0.18 -liter containers. There seemed to be a threshold between 0.18- and 0.36-liter container volumes for an effect on nutrient concentration, and this may have given rise to the strong curvilinear relationships of concentration vs. container volume. Hence, inadequate nutrition may have contributed to the decrease in growth for the 0.18-liter treatment, yet it is doubtful that growth reduction of trees in 0.36- and 0.9-liter containers (compared to 2.4-liter containers) resulted from nutritional factors. Deficiency signs were not observed on any trees, and our values of A were similar to light-saturated values reported for peach (Flore and Lakso, 1989). Severely deficient leaves would not be expected to assimilate $\mathrm{CO}_{2}$ at rates comparable to those of well-fertilized plants. In bean, doubling the nutrient solution concentration applied to confined root systems increased leaf nutrient content but did not increase growth (Carmi and Heuer, 1981), suggesting that growth of confined plants was not limited by mineral nutrition.

The uniform reduction in nutrient content for the 0.18 -liter container volume suggests a general effect of root confinement on nutrient accumulation, rather than a reduction in the ability to extract specific nutrients from the soil solution. In a related study, reductions in $\mathrm{N}, \mathrm{P}, \mathrm{Ca}, \mathrm{Mg}, \mathrm{Fe}, \mathrm{Al}$, and $\mathrm{Cu}$ occurred in Euonymus despite fertilization of confined plants five to six times daily (Dubik et al., 1990). These authors suggested that reduced root tip number and/or root length and an increase in root suberization in confined plants may have reduced ion uptake. Peach roots also decreased in number and length (data not shown), and appeared to be more suberized in response to root confinement, so it is possible that these factors caused reduced nutrient content in our study. Large changes in nutrient content observed here and previously (Dubik et al., 1990) when elaborate fertilization practices are used underscore the difficulty in eliminating nutrition as a factor controlling growth of plants confined to small soil volumes.

Greater starch accumulation in leaves of trees in smaller containers at week 13 corresponded well to the onset of sustained differences in A among treatments at week 12. Starch accumulation was associated with reduced A in sweet cherry by feedback inhibition (Gucci et al., 1991), and starch accumulation in leaves 
of confined cucumber plants was correlated with a 3-fold reduction in A (Robbins and Pharr, 1988). Increased sorbitol content for trees in smaller containers during week 9 may indicate that photosynthate export was limited at that time, since sorbitol is the major carbohydrate translocated in peach (Bieleski and Redgwell, 1985). Thus, earlier accumulation of photosynthate in leaves of trees in smaller containers may have precipitated the earlier and greater decline in A from week 9 to 16. However, differences in A at week 16 cannot be explained by feedback inhibition of carbohydrate because trees in smaller containers had similar or lower nonstructural carbohydrate content (Table 3).

The onset of growth reduction for root-confined trees was not caused by a limitation of photosynthesis or water deficit, although nutrient deficiency cannot be ruled out for severely restricted trees. The presence of root-derived hormonal signals that control growth of root-confined trees is currently under consideration. It is clear that growth control can be accomplished by root confinement in peach without materially affecting dry weight partitioning or producing signs of nutrient deficiency. Since fruiting efficiency is not negatively affected by root confinement (Ran et al., 1992; Williamson and Coston, 1990), confining roots to control peach tree growth seems promising, but may require greater attention to irrigation and fertility management.

\section{Literature Cited}

Beaudry, R.M., R.F. Severson, C.C. Black, and S.J. Kays. 1990. Banana ripening: Implications of changes in glycolytic intermediate concentrations, glycolytic and gluconeogenic carbon flux, and fructose 2,6bisphosphate concentration. Plant Physiol. 91:1436-1444.

Bieleski, R.L. and R.J. Redgwell. 1985. Sorbitol versus sucrose as photosynthesis and translocation products in developing apricot leaves. Austral. J. Plant Physiol. 12:657-668.

Blackman, P.G. and W.J. Davies. 1985. Root to shoot communication in maize plants of the effects of soil drying. J. Expt. Bot. 36:39-48.

Carmi, A., J.D. Hesketh, W.T. Enos, and D.B. Peters. 1983. Interrelationships between shoot growth and photosynthesis, as affected by root growth restriction. Photosynthetica 17:240-245.

Carmi, A. and B. Heuer. 1981. The role of roots in control of bean shoot growth. Ann. Bot. 48:519-527.

Couvillon, G.A. and A. Erez. 1980. Rooting, survival and development of several peach cultivars propagated from semihardwood cuttings. HortScience 15:41-43.

Dubik, S.P., D.T. Krizek, and D.P. Stimaart. 1990. Influence of root zone restriction on mineral element concentration, water potential, chlorophyll concentration, and partitioning of assimilate in spreading euonymus [E. Kiautschovica Loes. 'Sieboldiana']. J. Plant Nutr. 13:677-699.

Eissenstat, D.M. 1992. Costs and benefits of constructing roots of small diameter. J. Plant Nutr. 15:763-782.

Ferree, M.E. and S.C. Myers. 1989. Peach production handbook. Univ. of Ga., Athens. Expt. Stat. Hdbk. 1, p. 61-69.

Flore, J.A. and A.N. Lakso. 1989. Environmental and physiological regulation of photosynthesis in fruit crops. Hort. Rev. 11:111-157.

Geisler, D. and D.C. Ferree. 1984. Response of plants to root pruning. Hort. Rev. 6:155-188.

Gucci, R., P.D. Petracek, and J.A. Flore. 1991. The effect of fruit harvest on photosynthetic rate, starch content, and chloroplast ultrastructure in leaves of Prunus avium L. Adv. Hort. Sci. 5:19-22.

Hameed, M.A., J.B. Reid, and R.N. Rowe. 1987. Root confinement and its effects on the water relations, growth and assimilate partitioning of tomato (Lycopersicon esculentum Mill.). Ann. Bot. 59:685-692.

Krizek, D.T., A. Carmi, R.M. Mirecki, F.W. Snyder, and J.A. Bunce. 1985. Comparative effects of soil moisture stress and restricted root zone volume on morphogenetic and physiological responses of soybean [Glycine max (L.) Merr.]. J. Expt. Bot. 36:25-38.
Loreti, F., G. Scalabrelli, and O. Musso. 1989. Effect of paclobutrazol on productive behavior of peach under protected cultivation. Acta Hort. 239:285-288.

Marini, R.P. 1987. Growth and cropping of 'Redhaven' peach trees following soil application of paclobutrazol. J. Amer. Soc. Hort. Sci. 112:18-21.

Martin, G.C., F. Yoshikawa, and J.H. LaRue. 1987. Effect of soil applications of paclobutrazol on vegetative growth, pruning time, flowering, yield, and quality of 'Flavorcrest' peach. J. Amer. Soc. Hort. Sci. 112:915-921.

Masle, J. and J.B. Passioura. 1987. The effect of soil strength on the growth of young wheat plants. Austral. J. Plant Physiol. 14:643-656.

Myers, S.C. and A. Savelle. 1990. Effect of in-ground fabric containers on growth and fruiting of peach and apple. Proc. Southeastern Professional Fruit Workers Conf. 4:1-3.

Nightingale, G.T. 1935. Effects of temperature on the growth, anatomy, and metabolism of apple and peach roots. Bot. Gaz. 96:581-638.

Olien, W.C., R.E. Williamson, C.E. Hood, and D.R. Decoteau. 1991. Root pruning mature peach trees: first year effects. Proc. Southeastern Professional Fruit Workers Conf. 6:42-45.

Peterson, C.M., B. Klepper, F.V. Humphrey, and R.W. Rickman. 1984. Restricted rooting decreases tillering and growth of winter wheat. Agron. J. 76:861-863.

Peterson, T.A., M.D. Reinsel, and D.T. Krizek. 1991a. Tomato (Lycopersicon esculentum Mill., cv. 'Better Bush') plant response to root restriction. I. Alteration of plant morphology. J. Expt. Bot. 42:1233-1240.

Peterson, T.A., M.D. Reinsel, and D.T. Krizek. 1991b. Tomato (Lycopersicon esculentum Mill., cv. 'Better Bush') plant response to root restriction. II. Root respiration and ethylene generation. J. Expt. Bot. 42:12411249.

Pigeaire, A., J.S. Pate, and C.A. Atkins. 1990. Contrasting effects of rooting volume and aerial spacing on shoot morphology and reproductive performance of Lupinus angustifolius L. cv. Danja. Austral. J. Agr. Res. 41:339-350.

Ran, Y., B. Bar-Yosef, and A. Erez. 1992. Root volume influence on dry matter production and partitioning as related to nitrogen and water uptake rates by peach trees. J. Plant Nutr. 15:713-726.

Richards, D. and R.N. Rowe. 1977. Effects of root restriction, root pruning and 6-benzylaminopurine on the growth of peach seedlings. Ann. Bot. 41:729-740.

Ridley, J., P.J. Rathwell, and D.B. Luke. 1985. 1986-87 estimated costs and returns for commercial peaches, South Carolina. Clemson Univ. Coop. Ext. Serv. Ext. Econ. Rpt. 82.

Rieger, M. 1992. Growth, gas exchange, water uptake, and drought response of seedling- and cutting-propagated peach and citrus rootstocks. J. Amer. Soc. Hort. Sci. 117:834-840.

Rieger, M. and A. Motisi. 1990. Estimation of root hydraulic conductivity on intact peach and citrus rootstocks. HortScience 25:1631-1634.

Robbins, N.S. and D.M. Pharr. 1988. Effect of restricted root growth on carbohydrate metabolism and whole plant growth of Cucumis sativus $\mathrm{L}$. Plant Physiol. 87:409-413.

Rom, C.R. and D.C. Ferree. 1985. Time and severity of summer pruning influences on young peach tree net photosynthesis, transpiration, and dry weight distribution. J. Amer. Soc. Hort. Sci. 110:455-461.

Rom, R.C. 1983. The peach rootstock situation: An international perspective. Fruit Var. J. 37(1):3-14.

Ruff, M.S., D.T. Krizek, R.M. Mirecki, and D.W. Inouye. 1987. Restricted root zone volume: Influence on growth and development of tomato. J. Amer. Soc. Hort. Sci. 112:763-769.

Tennant, D. 1975. A test of a modified line intersect method of estimating root length. J. Ecol. 63:995-1001.

Tschaplinski, T.J. and T.J. Blake. 1985. Effects of root restriction on growth correlations, water relations, and senescence of alder seedlings. Physiol. Plant. 64:167-176.

Williamson, J.G. and D.C. Coston. 1990. Planting method and irrigation rate influence vegetative and reproductive growth of peach planted at high density. J. Amer. Soc. Hort. Sci. 115:207-212. 